\title{
REVIEW OF THE FIVE-YEAR FUNCTIONING OF THE FIRST SERBIAN BANK OF HUMAN MILK
}

\author{
Radmila Mileusnić-Milenović ${ }^{1}$, Ljiljana Pejčić ${ }^{2,3}$ \\ Institute of Neonatology, Belgrade, Serbia ${ }^{1}$ \\ Clinical Center Niš, Clinic for Children's Internal Diseases, Niš, Serbia² \\ University of Niš, Faculty of Medicine, Niš, Serbia ${ }^{3}$ \\ Contact: Radmila Mileusnić-Milenović \\ Institute of Neonatology \\ Kralja Milutina 50, Belgrade, Serbia \\ E-mail:radmilamilmil@yahoo.com
}

The first Serbian bank of human milk was founded in 2009 at the Institute of Neonatology in Belgrade and it has worked as a part of the Department of Mothers, Milk Bank, Enteral Cabinet and Consultative Infirmary. The aim of the paper is to show the functioning of the bank in the period from January 1, 2010 to December 31, 2014.

We analyzed the following elements: the number of admitted mothers, development of lactation, quantity of collected milk, quantity of milk related to its origin, number of donors of human milk from home environment. Our results showed the following: the number of mothers hospitalized at the Institute was on average about 29 per year. Large amounts of milk (about 4,400 I per year) are collected every year in the First Serbian Human Milan Bank. The biggest donation of milk comes from mothers whose children are hospitalized at the Institute, followed by donors from the home environment. The largest number of mothers (70-80\%) develop lactation in a certain period. The best year for the First Serbian Human Milk Bank was 2013. It is necessary to improve the system for collecting colostrum. Acta Medica Medianae 2017;56(2):85-91.

Key words: human milk bank, donor milk, neonatology 